\title{
CLINICAL AND ELECTROENCEPHALOGRAPHIC CHARACTERISTICS OF A COHORT OF PATIENTS WITH EPILEPSY AND ABSENCE SEIZURES
}

\author{
Soniza Vieira Alves-Leon', Maria Fátima Bento de Souza Cardoso², \\ Valéria Coelho Santa Rita Pereira ${ }^{3}$ Isabela D’Andrea Meira ${ }^{4}$
}

\begin{abstract}
Background: Epileptic syndromes with absence seizures (AS) possess unique clinical and electroencephalographic (EEG) characteristics. In typical or atypical AS, ictal phenomenology may include various characteristics. Vídeo-EEG monitoring enables findings to be correlated with ictal phenomenology. Objective: To evaluate the different AS in a cohort of patients with drug-resistant epilepsy (DRE) based on the International League against Epilepsy (ILAE)'s 2006 classification, to correlate with ictal phenomenology recorded and to apply the Panayiotopoulos criteria. Method: This study included patients with criteria of AS followed up at the Epilepsy Clinic. A dual, cross-sectional cohort study was carried out between 2005 and 2008. Patients receiving care in the Epilepsy Program of the HUCFF-UFRJ, who had been investigated by video-EEG and who presented clinical and EEG criteria for absence seizures, typical or atypical, according to the criteria defined by the ILAE, were included in the study, independent of age onset, the review of clinical history, age onset, family history, epilepsy onset and evolution, seizures phenomenology, antiepileptic drugs response and neuroimaging studies were used to classify the patients among the different epileptic syndrome associated to absence seizures. Results: Typical absences were more frequent (71.4\%) than atypical absences. Cases of juvenile absence epilepsy were the most frequent $(19 \%)$ in this series, followed by childhood absence epilepsy (14.4\%) and juvenile myoclonic epilepsy (4.8\%). In 14 patients (66.67\%), diagnosis was modified from focal epilepsy to primary generalized epilepsy. Clinical and EEG diagnosis of absence epilepsy resulted in a dramatic improvement in the control of seizures following modification of diagnosis and indication of an appropriate antiepileptic drug. Conclusion: Our results show that typical AS are more frequent than atypical. AS was successfully defined in 10 patients following application of Panayiotopoulos' criteria. The consequent change in diagnosis and therapy resulted in resolution of refractoriness in 9 patients. We concluded that in DRE, AS associated to unusual ictal phenomenology improve dramatically when diagnosed by video-EEG, permitting seizures to be controlled. Clinical and EEG evaluation confirm that myoclonus, automatisms and autonomic disorders are involved and that the consciousness may be affected to different degrees.
\end{abstract}

KEY WORDS: absence seizures, epilepsy, Panayiotopoulos.

\begin{abstract}
Caracteristicas clínicas e eletrencefalográficas de uma coorte de pacientes com epilepsia com crises de ausência

Resumo - Síndromes epilépticas com crises de ausência (CA) possuem características clínicas e eletroencefalográficas (EEG) únicas. Nas crises de ausência típica ou atipica, a fenomenologia ictal pode incluir características que podem levar ao erro diagnóstico e à indicação de drogas antiepilépticas que pioraram o quadro. Quando esses pacientes são referidos a um Programa de Epilepsias para investigação, a monitorização
\end{abstract}

\footnotetext{
'MD, PhD, Professora Associada a Universidade Federal do Estado do Rio de Janeiro (UNIRIO), Docente Permanente do Programa de Pós-Graduação em Neurologia da UNIRIO, Médica Responsável do Programa de Epilepsias do Serviço de Neurologia do Hospital Universitário Clementino Fraga Filho da Universidade Federal do Rio de Janeiro (HUCFF/UFRJ); ${ }^{2} \mathrm{MD}, \mathrm{MCs}$, Mestre pela UNIRIO, Doutorado em andamento no programa de Pós Graduação da UNIRIO, Médica Responsável pelo Ambulatório de Epilepsias do Serviço de Neurologia da Santa Casa de Misericórdia do Rio de Janeiro; ${ }^{3} \mathrm{MD}$, Mestranda do Programa de Pós-Graduação da UFRJ, Médica do Programa de Epilepsias do HUCFF/UFRJ; ${ }^{4}$ MD, PhD, Mestre pela UNIFESP, Doutora pela UFRJ, Médica do Programa de Epilepsias do HUCFF/UFRJ.
}

Received 12 April 2009, received in final form 28 July 2009. Accepted 11 August 2009.

Dra. Soniza Vieira Alves-Leon - Programa de Pós Graduação da Universidade Federal do Estado do Rio de Janeiro (UNIRIO) - Rua Mariz e Barros 775 20270-002 Rio de Janeiro RJ - Brasil.E-mail: sonizavleon@globo.com 
por vídeo-EEG permite correlacionar os achados eletrográficos com a fenomenologia ictal. Objetivo: Identificar em uma coorte de pacientes com epilepsia fármaco-resistente (EFR), pacientes com CA segundo critérios propostos pela Liga Internacional contra a Epilepsia (ILAE) de 2006, correlacionar a fenomenologia ictal ao EEG e aplicar os de critérios Panayiotopoulos neste grupo. Método: Estudo de corte transversal incluiu doentes encaminhados ao Programa de Epilepsia do HUCFF-UFRJ entre 2005 e 2008, investigados por vídeo-EEG e que apresentavam os critérios clínicos e EEG para CA típicas ou atípica; a revisão da história clínica, idade início, história familiar de epilepsia, evolução, a fenomenologia ictal, resposta a drogas antiepilépticas e estudos de neuroimagem foram utilizados para classificar os pacientes entre as diferentes sindromes epilépticas associadas a CA. Resultados: As CA típicas foram mais freqüentes (71,4\%) do que as atípicas. Casos de epilepsia ausência juvenil ocorreram em 19\% desta série, seguido por epilepsia ausência infantil (14,4\%) e epilepsia mioclônica juvenil (4,8\%). Em 14 pacientes (66,67\%), o diagnóstico de epilepsia focal epilepsia foi modificado para epilepsia generalizada primária. A mudança do diagnóstico de epilepsia focal para epilepsia com CA, seguido da troca para DAE adequadas, resultou em melhoria no controle de crises. Conclusão: Nossos resultados mostram que as CA típicas são mais freqüentes do que as atípicas. Em 10 pacientes, a aplicação dos critérios de Panayiotopoulos foi possivel. A conseqüente mudança no diagnóstico e terapêutica resultou na resolução de refratariedade em 9 pacientes. Concluímos que a fenomenologia ictal incomun em pacientes com CA contribui para o diagnóstico errôneo de epilepsia de difícil controle, e que o diagnostico por vídeo-EEG, permitiu a mudança do diagnóstico e a melhora dramática no controle das crises. As avaliações clínica e eletrencefalográfica confirmam que mioclonias, automatismos psicomotores e desordens autonômicas podem fazer parte da fenomenologia ictal de pacientes com CA e que a consciência pode ser afetada em diferentes graus.

PALAVRAS-CHAVE: crises de ausência, epilepsia, Panayiotopoulos.

Absence seizures (AS) are classified under the category of generalized epilepsies; however, unlike other seizures, absence seizures possess clinical characteristics and electroencephalographic (EEG) patterns that are specific for this diagnosis ${ }^{1-3}$ and occur in different epileptic syndromes. Absence seizures may be divided into typical absences and atypical absences, according to EEG pattern. Absence seizures are present in a heterogenous group classified by the International League against Epilepsy (ILAE) into four epileptic syndromes: childhood absence epilepsy, juvenile absence epilepsy, juvenile myoclonic epilepsy and myoclonic absence epilepsy ${ }^{4}$. Typical absence seizures are most frequent and are characterized by loss of consciousness which is time-locked with bursts of bilaterally synchronous spike-and-wave discharges of 3 to 4 cycles per second, and, in general, present good response to pharmacological treatment. Conversely, atypical absence seizures are less frequent, the seizures are associated with 1 to 2 cycles per second spike-wave discharges and slow background rhythms for aging; they are often associated with severe neurologic impairment and poor response to treatment. The criteria proposed by Panayiotopoulos in 1997 for the classification of patients with typical absence seizures include a greater number of absence syndromes, some of which have not yet been recognized by the ILAE, such as phantom absences, absence epilepsy with eyelid myoclonus and early-onset absence epilepsy, among others ${ }^{5}$.

Epilepsies with typical absence seizures are common forms of generalized epilepsy. Cases of childhood absence epilepsy constitute $2-10 \%$ of all cases of epilepsy in chil- dren. Juvenile absence epilepsy constitutes $10 \%$ of all cases of idiopathic generalized epilepsy, whereas absence epilepsy with eyelid myoclonus makes up $2 \%$ of all epilepsies and $11 \%$ of all cases of idiopathic generalized epilepsy. It is difficult to determine the frequency of the rarer syndromes ${ }^{6}$. Epilepsy was classified into focal and generalized forms rather more for didactic purposes than from any intention to define the localization of the disease, bearing in mind that various authors have questioned the essentially bilateral onset of the generalized forms of epilepsy, believing all to have a focal onset ${ }^{7,8}$. Interictal EEG may result in an incorrect diagnosis of the type of seizure and/or epileptic syndrome, following which therapy may consequently fail ${ }^{7}$, particularly in cases of patients with generalized epilepsy in whom clinical characteristics are suggestive of focal epilepsy during seizures or as a result of focal patterns revealed by interictal EEG.

The objective of this study was to evaluate with what frequency patients referred to the Epilepsy Program of the Clementino Fraga Filho Teaching Hospital, Federal University of Rio de Janeiro (HUCFF-UFRJ) with an initial diagnosis of drug-resistant epilepsy present absence seizures, analyze what clinical and electroencephalic variables were associated with drug-resistance, and reclassified this patients according to Panayiotopoulus criteria.

\section{METHOD}

A dual, cross-sectional cohort study was carried out between 2005 and 2008. Patients receiving care in the Epilepsy Program of the HUCFF-UFRJ, who had been investigated by vid- 
eo-EEG and who presented clinical and EEG criteria for absence seizures, typical or atypical, according to the criteria defined by the ILAE, were included in the study, independent of age onset; the review of clinical history, age onset, family history, epilepsy onset and evolution, seizures phenomenology, antiepileptic drugs response and neuroimaging studies were used to classify the patients among the different epileptic syndrome associated to absence seizures. Patients included could present other seizures type, besides absence seizures. All the seizures were registered and the concomitance of different seizures phenomenology and EEG pattern were analyzed. The video-EEG monitoring was done for at least $24 \mathrm{~h}$, with a Neurotec ${ }^{\odot}$ machine of 32 channels, and the scalp electrodes were distributed according to the 10-20 system. Patients with focal epilepsy and other generalized epilepsy without the presence of absence seizures were excluded. The clinical, ictal phenomenology and EEG variables were used to reclassify the patients according to Panayiotopoulus criteria analyzing the different epileptic syndromes with absence seizures.

This study was approved by the Institutional Review Board and all patients signed an informed consent form prior to admission. The clinical data and correlated variables recorded during video-EEG were stored on an Excel spreadsheet (Excel 19972003) and transformed into a DBF file to enable them to be read in the generally available Epi Info program, version 6.0.

\section{RESULTS}

Of a cohort of 643 patients receiving care between 2005 and 2008, 68 (10.57\%) were found to have clinical and EEG criteria for generalized epilepsy and, of these, 21 $(30.09 \%)$ had absence seizures. In these 21 patients, 2 presented clinical suspicion of generalized epilepsy according to seizures semiology and triggering factors described. The mean age of patients at the time of inclusion into the study was 25.5 years (range 3-58 years). The mean age at onset of symptoms was 11.8 years (range 1-39 years).

Of these 21 patients, the onset of symptoms occurred before the patient reached 10 years of age in 10 patients (47.6\%), between 11 and 20 years of age in another 10 $(4.76 \%)$ and after 20 years of age in 1 patient (4.76\%). Eight of these patients (38.09\%) were male. Twelve $(57.1 \%)$ were white, while $9(42.85 \%)$ were of African descent. The mean duration of the disease was 14.4 years (range 1-42 years). Six patients $(28.6 \%)$ had a family history of epilepsy, while $13(61.9 \%)$ did not and $2(9.5 \%)$ were unable to provide any information on the subject.

Of the 20 patients in use of antiepileptic drugs, 8 $(40 \%)$ were in use of specific first-line antiepileptic drugs for absence seizures and in 4 of these cases (50\%), these drugs were associated with other antiepileptics that are contraindicated for absence seizures, including: carbamazepine (CBZ) $(n=2)$, phenytoin (PHT) $(n=2)$ and oxcarbazepine (OCX) ( $n=2)$. Of the 4 remaining patients (50\%) us- ing specific first-line drugs for absence seizures, 1 patient $(25 \%)$ was using the drug as monotherapy, while the remaining 3 (75\%) were using the drug in association with another antiepileptic drug that was not contraindicated for absence seizures. A total of 14 patients (70\%) were using antiepileptic drug that were contraindicated for absence seizures. In 4 of these cases (28.58\%), the contraindicated antiepileptic drug was associated with a specific first-line drug for absence seizures, while in 5 patients (35.71\%) the drug was associated with a second contraindicated drug, in another $5(35.71 \%)$ the drug was associated with a second-line antiepileptic drug and in 2 patients (14.28\%) the contraindicated medication was being used as monotherapy. One patient without AED in the moment of the video-EEG monitoring fulfilled criteria to pharmacoresistant epilepsy but had interrupted the treatment by himself after worsening with carbamazepine and phenytoin.

Of the 14 patients in use of antiepileptic drugs that are contraindicated for absence epilepsy, the drug could not be withdrawn in 3 cases (21.42\%). However, in 7 patients $(50 \%)$, complete control of the seizures was achieved following withdrawal of the deleterious drugs, while in four cases (28.56\%) partial control was achieved, although occasional absence seizures persisted.

Of the four patients who were in use of specific firstline antiepileptic drugs for absence seizures, adjustment of the dose was effective in 1 patient (25\%). In another patient (25\%), in addition to adjustment of the dose, another antiepileptic drug had to be associated, a strategy that led to a reduction in the frequency of seizures. Despite all the relevant measures taken, seizures persisted in two patients.

Neuropsychological and motor development was normal in 18 patients (85.7\%) and abnormal in 3 (14.3\%). In 17 patients $(81.0 \%)$, there was no loss of function following the onset of seizures, whereas in $4(19 \%)$ there was a decline in neuropsychological and motor development.

Two patients (9.52\%) had only absence seizures, while 16 (76.19\%) had generalized tonic-clonic seizures, 6 (28.57\%) had appendicular myoclonus, 5 (23.80\%) had eyelid myoclonus with absences and 4 (19.04\%) had astatic seizures. Of the 21 patients, $2(9.52 \%)$ had one single type of seizure, 11 (52.38\%) had two associated types of seizure, $5(23.80 \%)$ had three associated types of seizure, 2 (9.52\%) had four associated types of seizure and 1 patient (4.76\%) had five different types of seizure. Four patients (19.04\%) had a previous history of status epilepticus, 3 of which (75\%) consisted of absence epilepsy and 1 case (25\%) of tonic clonic seizures (Table 1).

During the absence seizures, 5 patients $(23.80 \%)$ had no motor phenomena, 10 (47.61\%) had eyelid myoclonus, $7(33.33 \%)$ had appendicular myoclonus, 3 (14.28\%) had associated automatisms (Fig 1) and 2 (9.52\%) had autonom- 
Table 1. Seizures phenomenology and antiepileptic drug response.

\begin{tabular}{|c|c|c|c|}
\hline Patient & Other associated seizures & $\begin{array}{l}\text { Absence seizures concurrent } \\
\text { phenomenology }\end{array}$ & AED response \\
\hline 1 & & $\begin{array}{l}\text { Absence and eyelid myoclonus } \\
\text { masticatory automatism }\end{array}$ & \\
\hline 2 & Generalized tonic clonic & Absence and appendicular myclonus & Worsening after CBZ \\
\hline 3 & $\begin{array}{l}\text { Eyelid myoclonus Generalized tonic } \\
\text { clonic and appendicular myoclonus }\end{array}$ & Absence and eyelid myoclonus & Worsening after CBZ \\
\hline 4 & & $\begin{array}{l}\text { Absence and eyelid myoclonia, oral } \\
\text { and tongue automatism, upper } \\
\text { and lower limbs automatism }\end{array}$ & Worsening after CBZ \\
\hline 5 & Generalized tonic clonic, tonic and astatic & $\begin{array}{l}\text { Absence with upper and } \\
\text { lower limbs automatism }\end{array}$ & \\
\hline 6 & $\begin{array}{l}\text { Absence epilepsy, Generalized tonic } \\
\text { clonic and eyelid myoclonus }\end{array}$ & $\begin{array}{l}\text { Absence and eyelid myoclonus, } \\
\text { sometimes with epigastric discomfort }\end{array}$ & Worsening after CBZ \\
\hline 7 & Generalized tonic clonic & Brief absences & \\
\hline 8 & Astatic seizures and focal seizures & $\begin{array}{l}\text { Absence and eyelid myoclonus, } \\
\text { and astat seizures }\end{array}$ & $\mathrm{CBZ}$ and no worsening \\
\hline 9 & $\begin{array}{l}\text { Absence and upper and } \\
\text { lower limbs myoclonus }\end{array}$ & $\begin{array}{l}\text { Absence and upper and } \\
\text { lower limbs myoclonus }\end{array}$ & Worsening after CBZ \\
\hline 10 & Generalized tonic clonic & Absences and eyelid myoclonus & Worsening after CBZ \\
\hline 11 & Generalized tonic clonic & Brief absences & \\
\hline 12 & Generalized tonic clonic, astatic seizures & $\begin{array}{l}\text { Absences and eyelid myoclonus, } \\
\text { appendicular myoclonus, } \\
\text { sometimes astatic seizures }\end{array}$ & \\
\hline 13 & $\begin{array}{l}\text { Generalized tonic clonic, } \\
\text { release sphincteric }\end{array}$ & $\begin{array}{l}\text { Absences and episodic } \\
\text { confusional states }\end{array}$ & Worsening after CBZ \\
\hline 14 & $\begin{array}{l}\text { Generalized tonic clonic, episodic } \\
\text { confusional states and aggression }\end{array}$ & Brief absences & Worsening after CBZ \\
\hline 15 & $\begin{array}{l}\text { Generalized tonic clonic preceded by } \\
\text { upper and lower limbs myoclonus }\end{array}$ & $\begin{array}{l}\text { Absences with appendicular } \\
\text { myoclonus }\end{array}$ & Worsening after CBZ \\
\hline 16 & $\begin{array}{l}\text { Generalized tonic clonic, confusional } \\
\text { sates episodic, eyelid, upper } \\
\text { and lower limbs myoclonus }\end{array}$ & $\begin{array}{l}\text { Absence associated with eyelid } \\
\text { and appendicular myoclonus }\end{array}$ & \\
\hline 17 & $\begin{array}{l}\text { Generalized tonic clonic, upper } \\
\text { and lower limbs myoclonus }\end{array}$ & $\begin{array}{l}\text { Absence, sometimes associated } \\
\text { to masticatory movments }\end{array}$ & $\begin{array}{l}\text { Worsening after } \\
\text { OXCBZ }\end{array}$ \\
\hline 18 & Generalized tonic clonic & Brief absences & \\
\hline 19 & Eyelid myoclonus & Absences and eyelid myoclonus & Worsening after CBZ \\
\hline 20 & $\begin{array}{l}\text { Generalized tonic clonic, eyelid, upper } \\
\text { and lower limbs myoclonus, astat seizures }\end{array}$ & Absences and eyelid myoclonus & \\
\hline 21 & Generalized tonic clonic & Brief absences & \\
\hline
\end{tabular}

AED: antiepileptic drug; CBZ: carbamazepine; OXCBZ: oxcarbazepine.

ic abnormalities, while in 1 patient $(4.76 \%)$ there was a report of sphincter release and in another (4.76\%) a report of epigastric discomfort.

Ictal EEG findings were characteristic of generalized seizures, fulfilling the criteria for typical or atypical absence seizures in all patients. In 15 patients (71.4\%), videoEEG findings fulfilled the criteria for typical absence sei- zures (Fig 1) and in 6 patients (28.6\%) findings were characteristic of atypical absence seizures (Fig 2). Interictal EEG findings showed focal electroencephalographic elements in 14 patients (66.66\%), in combination with diffuse slowing of the brain electrical activity in one case $(7.14 \%)$ and generalized spike wave patterns in another (7.14\%). Five patients (23.80\%) had fragments of electroencephalographic 


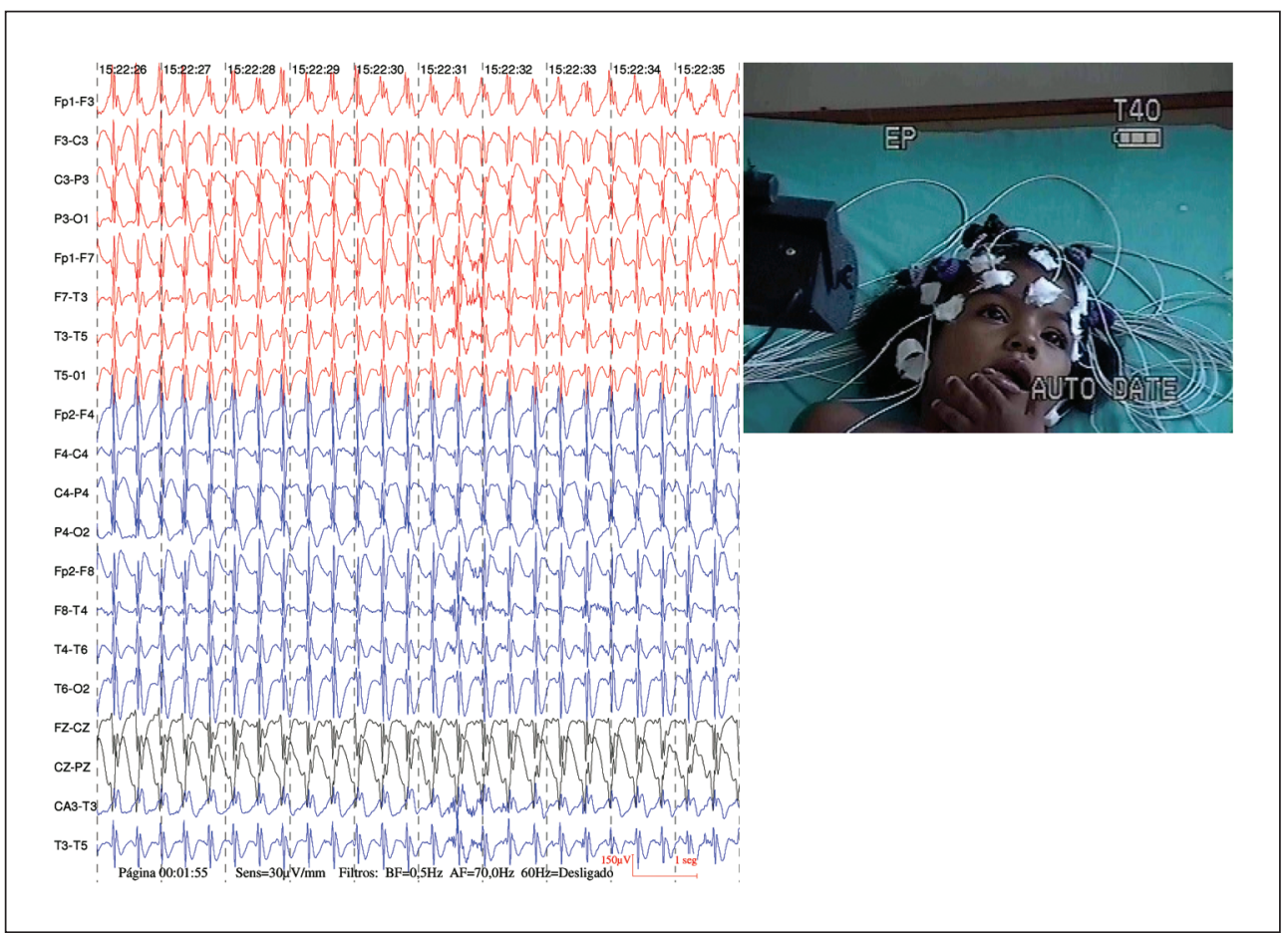

Fig 1. Registered ictal video-electroencephalographic showing complex of spike slow waves rhythmic of $3 \mathrm{~Hz}$, high amplitude, with projection widespread, synchronous and symmetrical, with duration of 18 seconds. Clinically, seizures of absence with eyelid myoclonia, perioral and language automatism.

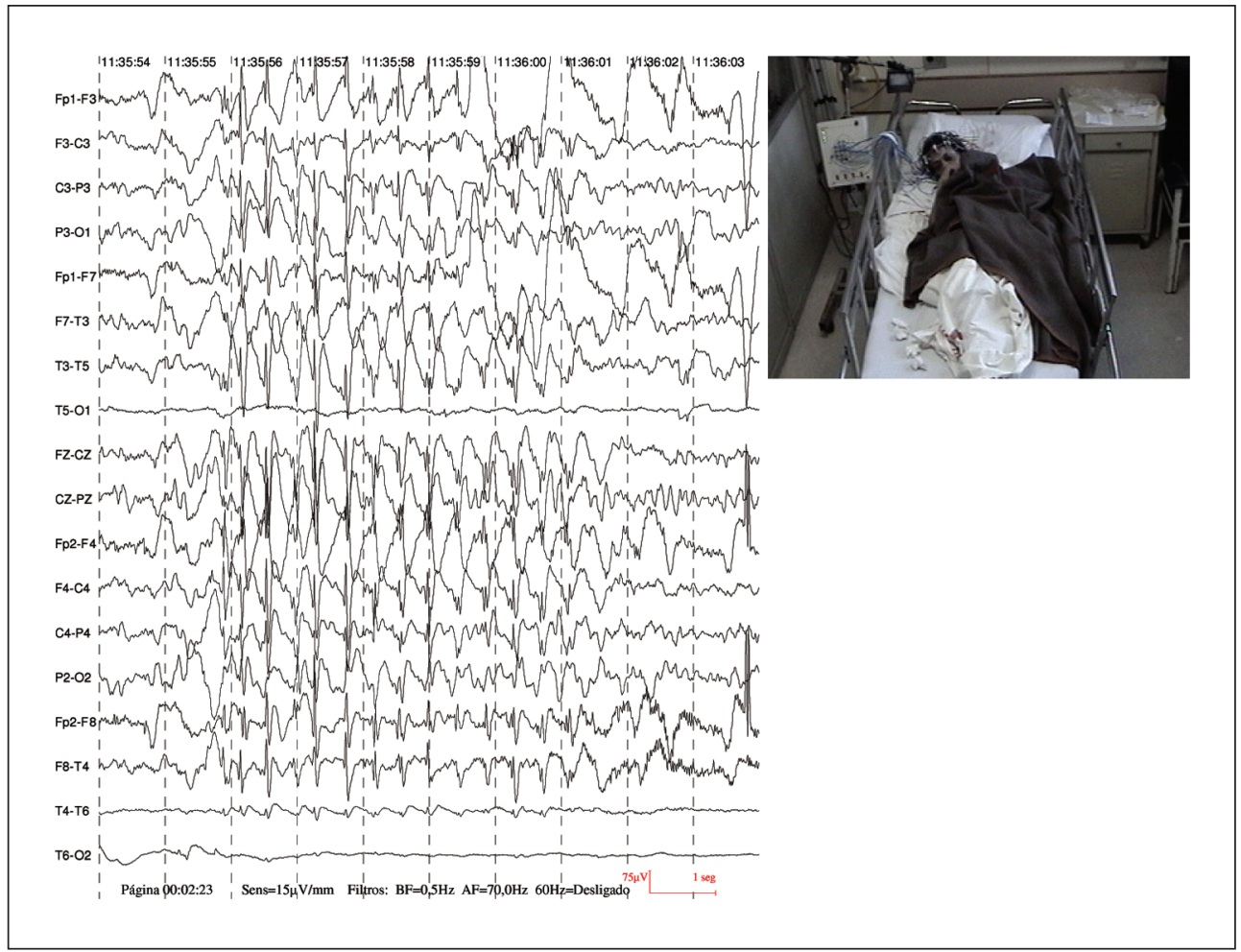

Fig 2. Record video-electroencephalographic evidence outbreak of spike wave complex and poly spike wave complex, about $2.5 \mathrm{~Hz}$, high amplitude, with widespread projection. 
Table 2. Results of ictal and interictal video-EEG.

\begin{tabular}{|c|c|c|c|c|c|c|}
\hline Patient & Interictal vídeo-EEG & Ictal vídeo-EEG & Hiperpnea & $\begin{array}{l}\text { Light } \\
\text { stimulus }\end{array}$ & $\begin{array}{l}\text { Diagnosis before } \\
\text { Pann Criteria }\end{array}$ & $\begin{array}{l}\text { Diagnosis after Pann } \\
\text { Criteria applyed }\end{array}$ \\
\hline 1. & $\begin{array}{l}\text { Irregular slow waves, acute } \\
\text { frontal waves temporal left }\end{array}$ & Complex spike slow wave $3 \mathrm{~Hz}$ & ++ & - & JAE & JAE \\
\hline 2. & $\begin{array}{l}\text { Spike complex and poli } \\
\text { spike slow wave frontal } \\
\text { and central bilateral }\end{array}$ & $\begin{array}{l}\text { Spike complex, irregular } \\
\text { and generalized poli spike } \\
\text { slow wave }(2.5-3 \mathrm{~Hz})\end{array}$ & ++ & - & JME & JME \\
\hline 3. & $\begin{array}{l}\text { Intermittent slow } \\
\text { wave frontal right }\end{array}$ & $\begin{array}{l}\text { Spike complex and poli } \\
\text { spike slow wave intermittent } \\
\text { generalized }( \pm 4 \mathrm{~Hz})\end{array}$ & - & ++ & NC & ABEEM \\
\hline 4. & Occipital slow wave & $\begin{array}{l}\text { Complex spike slow wave } \\
\text { generalized } 3 \mathrm{~Hz}\end{array}$ & ++ & - & EAI & NC \\
\hline 5. & $\begin{array}{l}\text { Diffuse slow track, intermittent } \\
\text { slow waves on frontal left }\end{array}$ & $\begin{array}{l}\text { Complex spike slow } \\
\text { wave generalized } \\
2 \mathrm{~Hz} \text { and generalized slow } \\
\text { wave acute wave } 2 \mathrm{~Hz}\end{array}$ & NA & - & $\mathrm{AA}$ & $\mathrm{AA}$ \\
\hline 6. & $\begin{array}{l}\mathrm{CE} \text { and poli spike slow } \\
\text { wave fronto central }\end{array}$ & $\begin{array}{l}\text { CE and intermittent poli spike } \\
\text { slow wave generalized } 3-4 \mathrm{~Hz}\end{array}$ & - & - & CAE & $\begin{array}{l}\text { Phantom } \\
\text { absences }\end{array}$ \\
\hline 7. & $\begin{array}{l}\text { CE and poli spike slow } \\
\text { wave fronto temporal }\end{array}$ & $\begin{array}{l}\text { CE e intermittent poli spike } \\
\text { slow wave generalized } 3-4 \mathrm{~Hz}\end{array}$ & ++ & - & NC & $\begin{array}{l}\text { Phantom } \\
\text { absences }\end{array}$ \\
\hline 8. & $\begin{array}{l}\text { Irregular slow waves } \\
\text { on temporal left }\end{array}$ & $\begin{array}{l}\text { Complex spike slow wave } \\
\text { generalized } 1.5-2 \mathrm{~Hz}\end{array}$ & + & - & AA & NC \\
\hline 9. & $\begin{array}{l}\text { Irregular acute wave } \\
\text { and slow wave }\end{array}$ & $\begin{array}{l}\text { Complex spike slow wave } \\
\text { generalized } 3-4 \mathrm{~Hz}\end{array}$ & ++ & - & JAE & NC \\
\hline 10. & $\begin{array}{l}\text { CE e poli spike slow } \\
\text { wave on frontal left }\end{array}$ & $\begin{array}{l}\text { CE intermittent poli spike slow } \\
\text { wave generalized } 3-4 \mathrm{~Hz}\end{array}$ & ++ & ++ & JAE & AEEM \\
\hline 11. & $\begin{array}{l}\text { Irregular slow wave } \\
\text { generalized }\end{array}$ & $\begin{array}{l}\text { Intermittent complex spike } \\
\text { slow wave generalized }\end{array}$ & - & + & NC & $\begin{array}{l}\text { Phantom } \\
\text { absences }\end{array}$ \\
\hline 12. & $\begin{array}{l}\text { Diffuse slow track; complex } \\
\text { spike slow wave fronto-central }\end{array}$ & $\begin{array}{l}\text { Complex spike slow wave } \\
\text { generalized } 2-2.5 \mathrm{~Hz}\end{array}$ & ++ & - & $\mathrm{AA}$ & NC \\
\hline 13. & $\begin{array}{l}\text { Complex spike slow } \\
\text { wave on frontal right }\end{array}$ & $\begin{array}{l}\text { Intermittent complex spike } \\
\text { slow wave generalized } 3-4 \mathrm{~Hz}\end{array}$ & - & - & NC & $\begin{array}{l}\text { Phantom } \\
\text { absences }\end{array}$ \\
\hline 14. & $\begin{array}{l}\text { Irregular slow waves } \\
\text { on parietal right }\end{array}$ & $\begin{array}{l}\text { CE and poli spike slow } \\
\text { wave generalized } 2.5 \mathrm{~Hz}\end{array}$ & + & + & NC & NC \\
\hline 15. & $\begin{array}{l}\text { EF and slow wave/acute wave } \\
\text { on frontal and temporal left }\end{array}$ & $\begin{array}{l}\text { CE and intermittent poli spike } \\
\text { slow wave generalized }\end{array}$ & + & + & JME & NC \\
\hline 16. & $\begin{array}{l}\text { Irregular slow waves on fronto- } \\
\text { temporal; generalized spikes }\end{array}$ & $\begin{array}{l}\text { Generalized spikes and } \\
\text { generalized poli spike slow wave }\end{array}$ & NA & - & $\mathrm{AA}$ & NC \\
\hline 17. & $\begin{array}{l}\text { Fronto temporal spikes } \\
\text { on right }\end{array}$ & $\begin{array}{l}\text { Intermittent generalized spike } \\
\text { slow wave complex } 2 \mathrm{~Hz}\end{array}$ & + & - & $\mathrm{AA}$ & NC \\
\hline 18. & $\begin{array}{l}\text { Acute and slow waves on } \\
\text { fronto-temporal left }\end{array}$ & $\begin{array}{l}\text { CE and generalized poli } \\
\text { spike slow wave } 3 \mathrm{~Hz}\end{array}$ & NA & - & NC & EAIP \\
\hline 19. & $\begin{array}{l}\text { Irregular acute and slow } \\
\text { wave on temporal left }\end{array}$ & $\begin{array}{l}\text { Generalized spike slow } \\
\text { wave complex } 3 \mathrm{~Hz}\end{array}$ & - & - & CAI & NC \\
\hline 20. & $\begin{array}{l}\text { Irregular slow waves on } \\
\text { fronto-temporal }\end{array}$ & $\begin{array}{l}\text { generalized spike slow } \\
\text { wave complex } 1.5-2.5 \mathrm{~Hz}\end{array}$ & + & + & $\mathrm{AA}$ & NC \\
\hline 21. & $\begin{array}{l}\text { Irregular acute slow wave } \\
\text { fronto-central rigth }\end{array}$ & $\begin{array}{l}\text { Generalized spike slow } \\
\text { wave complex } 3 \mathrm{~Hz}\end{array}$ & + & + & JAE & JAE \\
\hline
\end{tabular}

JAE: juvenil absence epilepsy; JME: juvenile myoclonic epilepsy; NC: not classified; EMAE: early myoclonic absence epilepsy; AEEM: absence epilepsy with eyelid myoclonus; CAE: childhood absence epilepsy; AA: atypical absence. 


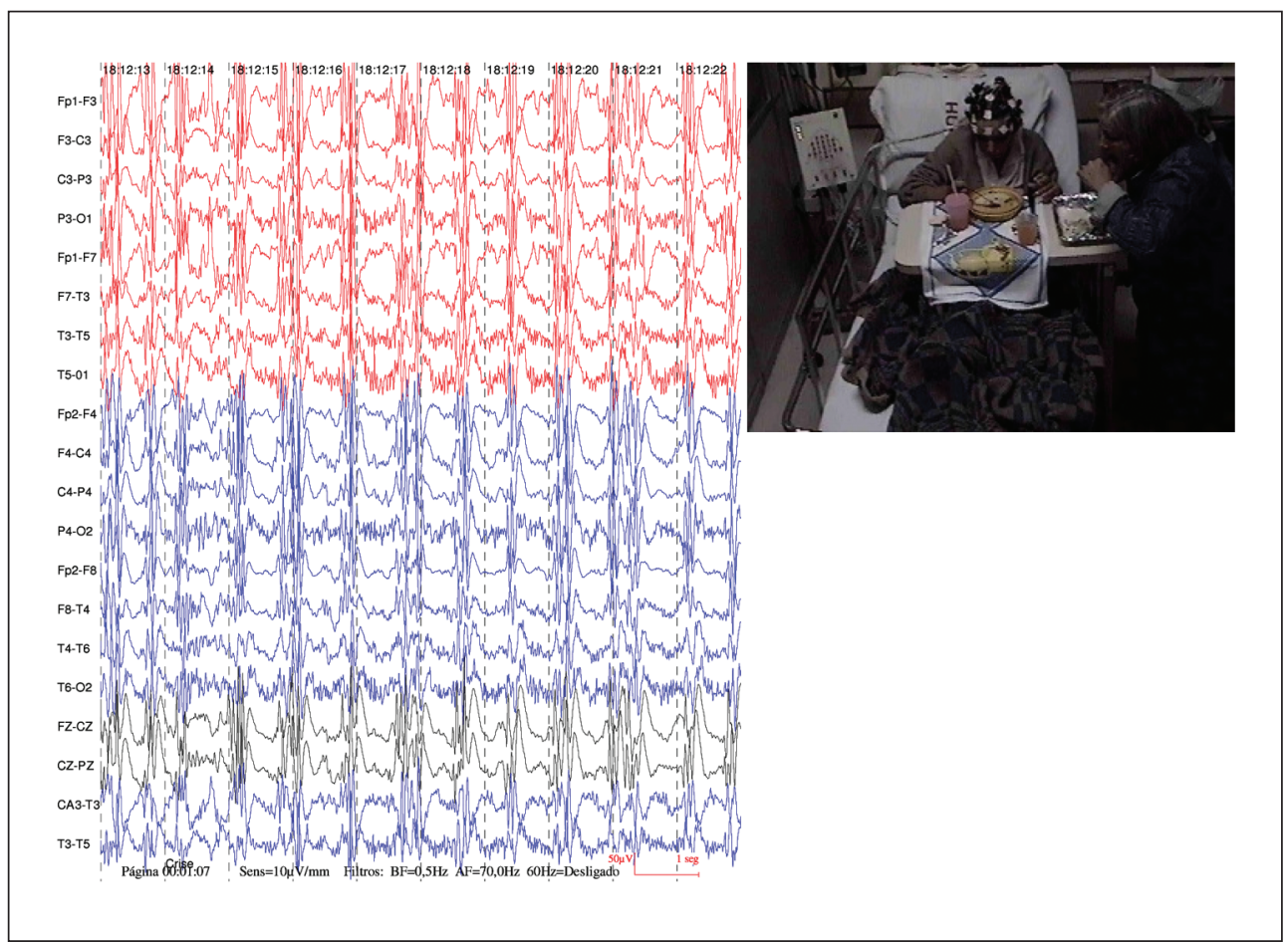

Fig 3. Registration ictal video-electroencephalographic evidence outbreak of poly spike wave complex, approximately $1.5 \mathrm{~Hz}$, high amplitude, with widespread projection. Clinically patient remains lunching with difficult in organizing movements for eating.

elements with a predominance of morphological characteristics similar to focal ictal features in a normal interictal tracing. Of these patients, 4 (80\%) had spike complexes and polyspike-slow wave complexes, and 1 patient $(20 \%)$ had spike-slow wave complex. In one patient (4.76\%), interictal recording showed slow wave and intermittent, generalized spike wave activity and in another patient $(4.8 \%)$, slowing of background activity in the EEG tracings was found in association with spike-slow wave complex (Table 2).

Ictal recording of 12 patients (57.4\%) with spike-slow wave complexes showed regular ictal discharge in 7 (58.3\%) and irregular ictal discharge in 5 (41.7\%). Of the 12 patients with spike-slow wave complex, frequency was $>2.5 \mathrm{~Hz}$ in $7(58.4 \%)$ and $\leq 2.5 \mathrm{~Hz}$ in 5 (41.7\%) (Table 2).

Of the 9 patients $(42.8 \%)$ in whom ictal recording registered spike complexes and polyspike-slow wave complexes, ictal activity was regular in 2 cases $(22.2 \%)$ and irregular in $7(77.8 \%)$. In 3 patients (33.3\%), frequency was $>2.5 \mathrm{~Hz}$, while in 1 patient (11.1\%), frequency was $\leq 2.5 \mathrm{~Hz}$, and in another (11.1\%) frequency varied between $>2.5 \mathrm{~Hz}$ and $\leq 2.5 \mathrm{~Hz}$ during seizures. In 2 patients (22.2\%) with spike complexes and polyspike-slow wave complexes $<2.5 \mathrm{~Hz}$, there was an association of spike-wave and slowwave paroxysms (Table 2).

Of the 18 patients $(85.7 \%)$ in whom hyperpnea was successfully accomplished, 13 (72.2\%) had abnormalities; $6(46.2 \%)$ had accentuated electroencephalographic el- ements and seizures were triggered in another 7 (53.8\%). Seven patients (33.3\%) had an abnormal EEG recording because of photic stimulation, 5 of these patients (71.4\%) having accentuated electroencephalographic elements while 2 (28.6\%) developed seizures as a result of photosensitivity. In three patients (14.3\%), the presence of eyelid myoclonus was registered following ocular occlusion in an illuminated environment, with absences in one patient.

Of the 21 patients evaluated, 15 (71.42\%) fulfilled clinical and EEG criteria for typical absences and 6 patients (28.58\%) for atypical absences. Of the 15 patients of the group with clinical and EEG characteristics of typical absences, $9(60 \%)$ were diagnosed with an epileptic syndrome, while $6(40 \%)$ were not classified as having any of the syndromes described by the ILAE. Of the 9 patients with an established epileptic syndrome, $5(55.6 \%)$ were classified as juvenile absence epilepsy, 3 (33.3\%) as childhood absence epilepsy and 1 (11.1\%) as juvenile myoclonic epilepsy. After applying Panayiotopoulos' criteria, 10 patients $(66.7 \%)$ were able to be diagnosed with specific syndromes, while $5(33.3 \%)$ failed to fulfill the criteria for any specific syndrome. Of the 10 patients with a specific classification, $2(20 \%)$ retained the diagnosis of juvenile absence epilepsy and $1(10 \%)$ of myoclonic absence epilepsy, while 4 (40\%) were classified as phantom absences (Fig 3), $2(20 \%)$ as absence epilepsy with eyelid myoclonus and $1(10 \%)$ as early-onset absence epilepsy. 


\section{DISCUSSION}

The present results show that some absence seizures may include ictal phenomena with both simple and complex motor automatisms, confounding diagnosis and leading to inappropriate therapy, as shown by Lombroso, Ferrie and Holmes, and Brown and Tucker, ${ }^{7,813}$. It can justify why patients with primary generalized seizures were referred to our video-EEG unit.

The rate $(10.57 \%)$ of patients with drug-resistant epilepsy at the HUCFF-UFRJ was lower than figures reported in the literature ${ }^{6,14}$ and may be attributable to the low rate of diagnosis or to the age group of the cohorts in those studies. In the present study, this finding may perhaps reflect the large number of patients with focal epilepsy referred to epilepsy programs such as that offered at the HUCFF, which receives a greater percentage of patients with supposedly focal seizures.

The age at onset of absence seizures, which ranged from 1 to 39 years, is justified by the inclusion of patients with different epileptic syndromes in which absence seizures are found. Each one of the syndromes is characterized by a certain age at onset according to the respective age-group. Another factor that may explain this wide range is the inclusion of patients with epileptic syndromes involving absence seizures that have not yet been recognized by the ILAE. These syndromes have, however, been the subject of recent studies and their inclusion into the ILAE classification has been proposed by various investigators ${ }^{1,5,9}$. One example is the patient in whom onset of absence seizures occurred in adulthood (at 39 years of age), a case similar to others previously reported by Trinka ${ }^{10}$. Another example was the patient with early onset at 12 months of age, other investigators also having reported similar cases ${ }^{9,10}$. Despite the disparate variation in age at onset, the mean age of patients at the onset of absence seizures in the present study was 11.04 years, which is in agreement with data reported from other studies on juvenile absence epilepsy ${ }^{12}$.

There was a predominance of females in the present study, which is in agreement with findings reported in the literature, principally in studies on generalized epilepsies with absence seizures ${ }^{13}$. There may be a predominance of males in cases of epilepsy with myoclonic absences ${ }^{13}$.

The duration of epilepsy found in this study was longer than expected. This finding is justified by the fact that patients with drug-resistant epilepsy require referral to specialized treatment centers as early as possible, as emphasized in the literature ${ }^{14,15}$. Erroneous initial diagnosis and the consequent inefficacy of the prescribed antiepileptic drugs was the most frequent finding. Syndromes such as atypical absences, which have a natural history of refractoriness to treatment, were another cause of drugresistant epilepsy ${ }^{16,17}$.
The present results are in agreement with reports in the literature where in some cases a family history of the condition was common and various different types of seizure were found in the same family ${ }^{3,18}$.

In 14 patients (70\%) in this series, an increase was found in the frequency of epileptic seizures that was attributed to the use of antiepileptic drugs that are contraindicated for patients with absence seizures, thereby confirming the importance of the new ILAE classification ${ }^{19}$, which now includes selective response to antiepileptic drugs as part of the classification criteria ${ }^{2,20-22}$. Incorrect diagnosis based on the presence of apparently focal characteristics ${ }^{23,24}$, as well as interictal EEG scans with focal abnormalities ${ }^{7}$, were also found in our patients and were confounding factors in the differential diagnosis with focal epilepsy. Indeed, differential diagnosis was only possible with the aid of video-EEG.

In the present series, four patients had limb and orofacial (mouth and tongue) automatisms highly suggestive of temporal epilepsy but which occurred during absence seizures and were correlated with EEG showing $3 \mathrm{c} / \mathrm{s}$ spikeslow wave complex or spike complex and generalized polyspike-slow wave. In another 9 patients, the presence of eyelid myoclonia was confused with facial automatisms or considered to constitute an event unrelated to epilepsy. In 8 patients, the presence of appendicular myoclonus was confused with temporal lobe automatisms. The diversity in the types of seizures found in patients with absence seizures in the present study is in agreement with reports in the literature ${ }^{13,23,24}$. This heterogeneity in the absence seizures found in patients with generalized epilepsy has been confirmed by other authors 6,10,12,13,23,24 $^{\text {. }}$

The finding of absence epilepsy in our patients is in agreement with reports in the literature that patients with absence seizures, albeit apparently asymptomatic, may progress to absence epilepsy or generalized tonicclonic seizures ${ }^{5,25-27}$.

In the present study, a greater association of atypical absence seizure was found in patients with a history of function loss following the onset of seizures, mental retardation and drug-resistant epilepsy. This finding is in agreement with the literature, confirming that atypical absence seizures are associated with a poorer prognosis with respect to the control of seizures, to impaired cognition and neuropsychological and motor development and to a greater variation in the types of seizures ${ }^{13,16,17}$. In the present study, patients with atypical absences had seizures associated with abnormal muscle tone, either hypo or hypertonia, and astatic seizures were more frequent in this group compared to reports from other studies published in the literature ${ }^{13,16,17,28}$.

A significant difference was found between the classification of patients in the present series according to the definitions of the ILAE $E^{4,19,29}$ and their posterior classifica- 
tion according to the criteria proposed by Panayiotopoulos et al ${ }^{1.5}$ According to Panayiotopoulos ${ }^{2}$, the classification of a specific syndrome is in agreement with the literature when application of the criteria used results in an increase in that classification category and a consequent improvement in the therapeutic options available to the respective patients ${ }^{1,5,24,30}$

We attribute the large rate of cases of phantom absences in this series to the fact that these patients had seizures that were difficult to diagnose, this type of referral being commonplace at specialized centers.

Analysis of this series of patients with absence seizures demanded a meticulous review of the currently proposed diagnostic criteria and showed that a careful evaluation of patients with drug-resistant epilepsy may result in a change in the initial diagnosis to a controllable form of epilepsy that is not drug-resistant. In almost $70 \%$ of the cases in the present series, modification and adaptation of the diagnosis of the epileptic syndrome or of the type of seizure altered therapeutical management and the quality of life of these patients and their families, confirming the importance of establishing referral centers for the investigation and treatment of epilepsy.

In conclusion, in patients with epilepsy with typical or atypical absence seizures, ictal phenomenology may include various characteristics, and clinical and EEG evaluation confirms that myoclonus, automatisms and autonomic disorders are involved and that the consciousness of the patient may be affected to different degrees. Typical absences are more frequent $(71.4 \%)$ than atypical absences. Cases of juvenile absence epilepsy were the most frequent $(19 \%)$ in this series, followed by childhood absence epilepsy (14.4\%) and juvenile myoclonic epilepsy (4.8\%). In 14 patients (66.67\%), diagnosis was modified from focal epilepsy to primary generalized epilepsy. AS was successfully defined in 10 patients following application of Panayiotopoulos' criteria. Clinical and EEG diagnosis of absence epilepsy resulted in a dramatic improvement in the control of seizures following modification of diagnosis and indication of an appropriate antiepileptic drug.

\section{REFERENCES}

1. Panayiotopoulus CP. Absence epilepsies. In: Engel JR (Ed) Epilepsy: a comprehensive textbook. Philadelphia: Lippincott-Raven Publishers; 1997:2327-2346.

2. Panayiotopoulus CP. Typical absence seizures and their treatment. Arch Dis Child 1999;81:351-355.

3. Engel JJ. Report of the ILAE Classification Core Group. Epilepsia 2006; 47:1558-1568.

4. Commission on classification and terminology of the International League Against Epilepsy: proposal for revised classification of epilepsies and epileptic syndromes. Epilepsia 1989;30:389-399.

5. Panayiotopoulus CP. Syndromes of idiophatic generalized epilepsies not recognized by the International League Against Epilepsy. Epilepsia 2005;45(Suppl 9):S57-S66.
6. Duron RM, Medina MT, Martínez-Juárez IE, et al. Seizures of idiophathic generalized epilepsies. Epilepsia 2005;46(Suppl 9):S34-S47.

7. Lombroso CT. Consistent EEG focalities detected in subjects with primary generalized epilepsies monitored for two decades. Epilepsia 1997;38:797-812.

8. Holmes MD, Brown M, Tucker DM. Are "generalized" seizures truly generalized? Evidence of localized mesial frontal and frontopolar discharges in absence. Epilepsia 2004;45:1568-1579.

9. Chaix, Y, Daquin, G, Monteiro, F, Villeneuve N, Laguitton V, Genton P. Absence epilepsy with onset before age three years: a heterogeneous and often severe condition. Epilepsia 2003;44:944-949.

10. Trinka E. Absences in adult seizure disordes. Acta Neurol Scand 2005; 112(Suppl 182):S12-S18.

11. Titomanlio L, Romano A, Bellini G, et al. Familial occurrence of earlyonset chidhood absence epilepsy. Eur J Paediatr Neurol 2007;11:178-180.

12. Valentin A, Hindocha N, Osei-Lah A, et al. Idiophathic generalized epilepsy with absences: sindrome classification. Epilepsia 2007;48: 2187-2190

13. Stefan H, Snead OC, Olofsson O. Typical and atypical absence seizures, mioclonic absences, and eyelid myovlonia. In: Engel JR J, Pedley TA (Eds). Epilepsy a comprehensive textbook. $2^{\text {th }}$ Ed. Philadelphia: Wolters Kluwer: Lippincott Williams \&Wilkins, 2007:572-584.

14. Devinsky O. Current concepts: patients with refractory seizures. N Engl J Med 1999;340:1565-1570.

15. Arroyo S. Evaluatión de La epilepsia farmacorresistente. Rev Neurol 2000;30:881-886.

16. Bare MB, Glauser TA, Strawsburg RH. Need for electroencephalogram video confirmation of atypical absence seizure in children with LennoxGastaut syndrome. J Child Neurol 1998;13:498-500.

17. Holmes GL. Generalized seizures. In: Swaikman K, Ashwal S (Eds) Pediatric neurology: principles \& practice. $4^{\text {th }} \mathrm{Ed}$. Minnesota: Elservier, 1999:643-645

18. Winawaer MR, Marini C, Grinton BE, et al. Familial clustering of seizures types within the idiophatic generalized epilepsies. Neurology 2005;65:523-528.

19. Engel JJ. ILAE classification of epilepsy syndromes. Epilepsy Res 2006; 70(Suppl):S5-S10.

20. Liporace JD, Sperling MR, Dichter MA. Abcence seizures and carbamazepine in adults. Epilepsia 1994;35:1026-1028.

21. Genton P. When antiepileptic drugs aggravate epilepsy? Brain Dev 2000;22:75-80.

22. Gelisse P, Genton I, Kuatec C, Pesenti A, Baldy-Moulinier M, Crespel A. Worsening of seizures by oxcabazepine in juvenile idiopathic generalized epilepsies. Epilepsia 2004;45:1282-1286.

23. Mory SB, Guerreiro CAM, Lim L, et al. Epilepsias generalizadas idiopáticas diagnosticadas incorretamente como epilepsias parciais. Arq Neuropsiquiatr 2002;60:788-796.

24. Guilhoto MFF, Manreza ML, Yacubian EM. Syndromic classification of patients with typical absence seizures. Arq Neuropsiquiatr 2003;61: 580-587.

25. Baykan B, Noachtar S. Perioral myoclonia with absences: an overlooked and misdiagnosed generalized seizure type. Epilepsy Behav 2005;6: 460-462.

26. Shorvon S, Walker M. Status epilepticus in idiopathic generalized epilepsy. Epilepsia 2005;46(Suppl, 9):S73-S79.

27. Genton P, Felarzzo E, Thomas P. Absence status epilepsy: delineation of a distinct idiopathic generalized epilepsy syndrome. Epilepsia 2008; 49:642-648.

28. Niedermeyer E. Epileptic seizure disorders. In: Niedermeyer E, Silva FL (Eds) Electroencephalography: basic principles, clinical applications, and related fields. $4^{\text {th }}$ Ed. Baltimore: Lippincott Willians \& Wilkins, 1998:476-585.

29. Commission on classification and terminology of the international league against epilepsy. Proposal for revised clinical and electroencephalographic classification of epileptic seizures. Epilepsia 1981;22:489-501.

30. Giannakodimos S, Panayiotopulos CP. Eyelid myiclonia with absences in adults: a clinical and video-EEG study. Epilepsia 1996;37:36-44. 